\title{
Covid-19 Pandemi Döneminde Uzaktan Çalışma Uygulamaları ve Çalışma Motivasyonunu Etkileyen Faktörler (Remote Working Practices and the Factors Affecting Work Motivation During The Covid- 19 Pandemic Period)
}

\author{
Ayşen AKBAŞ TUNA iD a Zafer TÜRKMENDAĞ \\ a Ankara Hacı Bayram Veli Üniversitesi, Bankacılık ve Sigortacılık Yüksekokulu, Ankara, Türkiye. aysenakbastuna@hotmail.com \\ b Atatürk Üniversitesi, Turizm Fakültesi Turizm Rehberliği Bölümü, Erzurum, Türkiye. zafer.turkmendag@gmail.com
}

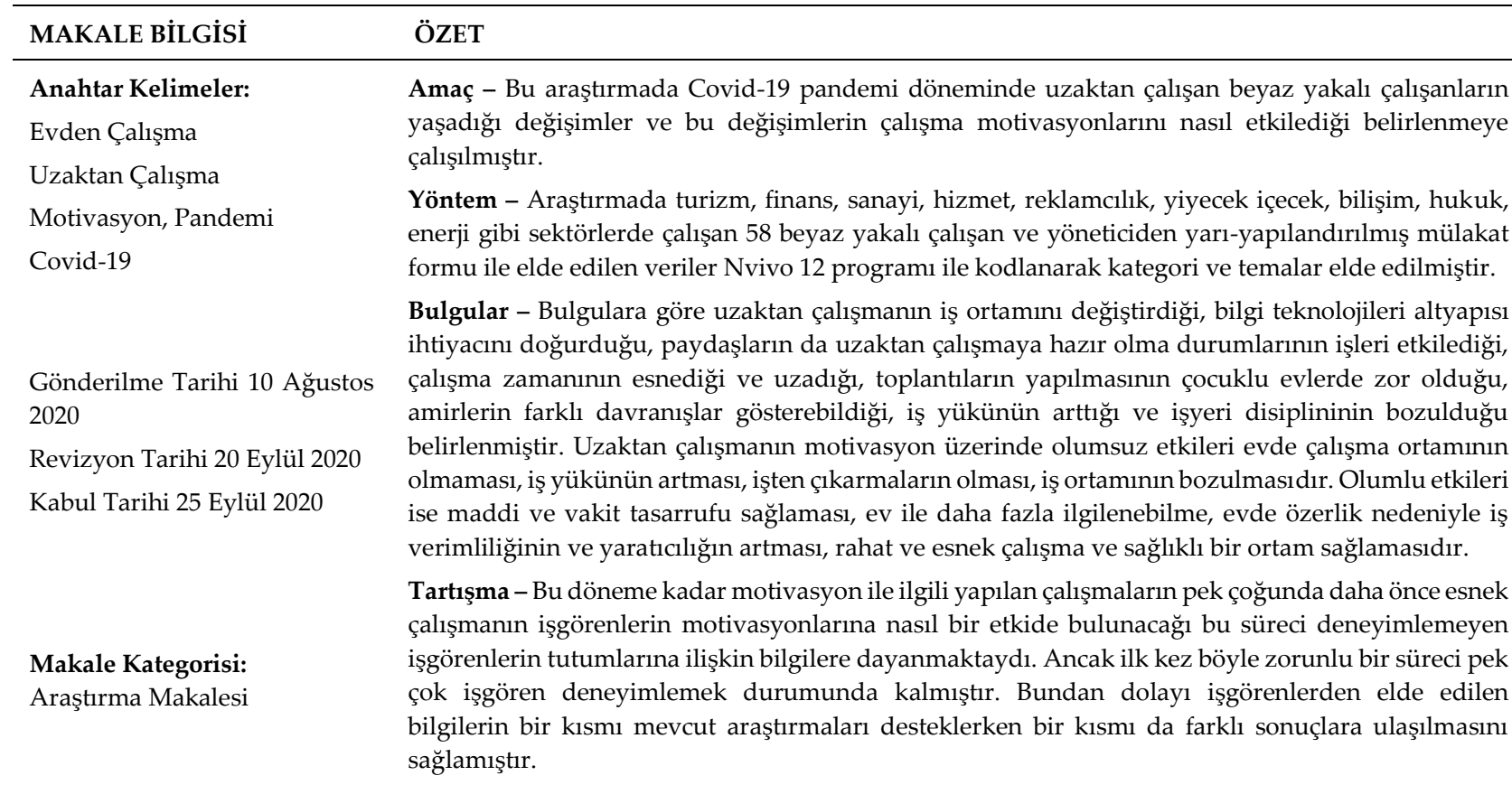

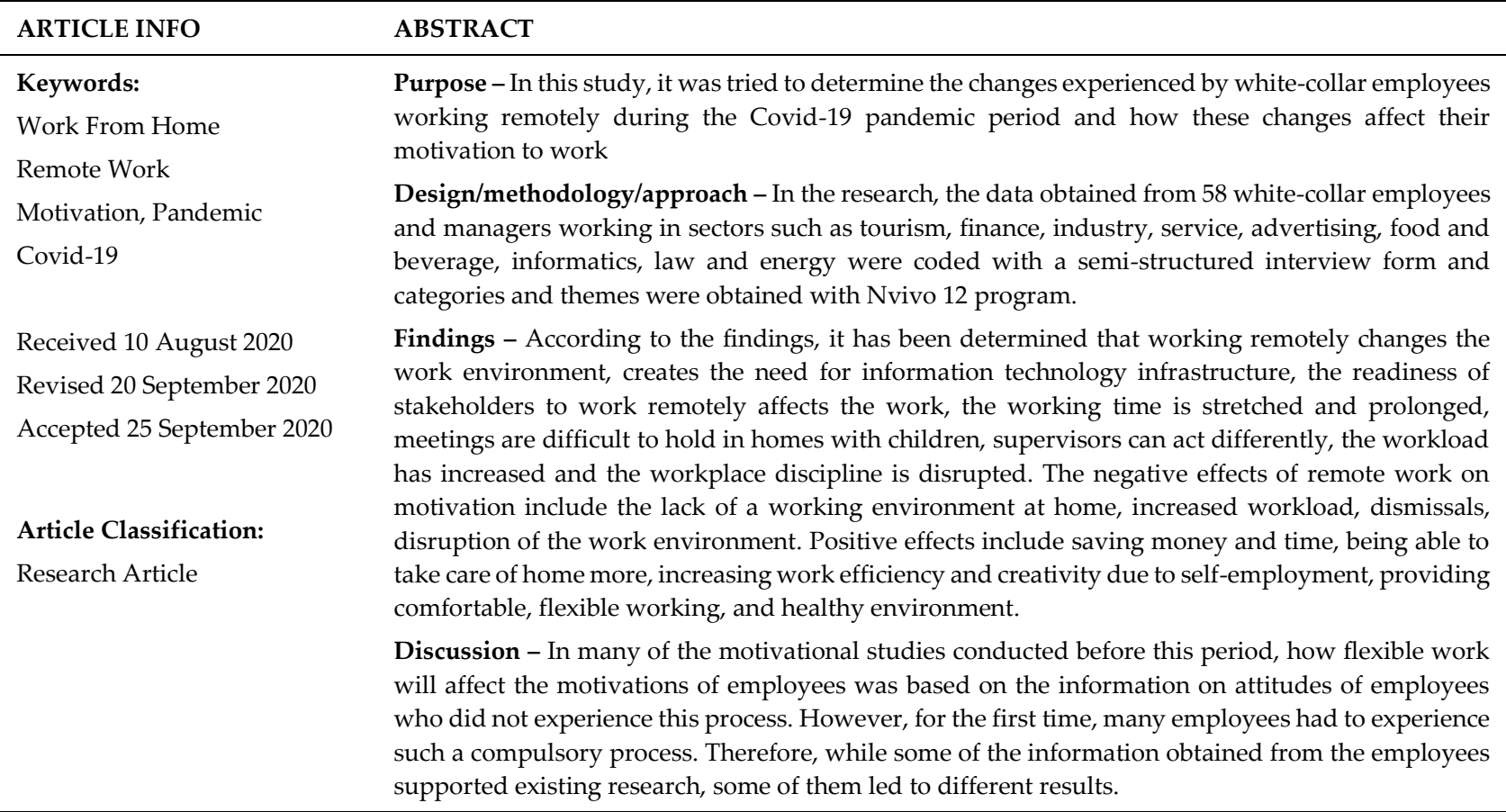




\section{GİRIŞ}

Covid-19 Pandemisi'nin tehlikeli boyutlara ulaşmasıyla devletler çeşitli önlemler alarak halkın korunabilmesini sağlamıştır. Bunlardan en etkilileri sokağa çıkma yasağı ve sosyal izolasyon olduğundan çalışanlar işyerlerine uzun bir süre gidememiştir. Bunun yanında şirketler de tehlikenin farkında olduğundan ve/veya ekonomik zorunluluklar nedeniyle çalışanlarına yönelik ücretsiz izin verme, işten çıkarma veya uzaktan çalışma gibi uygulamalar gündeme gelmiştir. Esnek çalışma modellerinden biri olan uzaktan ya da evden çalışma yöntemi pandemi döneminde hem halk sağlığını hem de bu sürecin ekonomi üzerindeki olumsuz etkilerini hafifletmek açısından önem kazanmıştır. Böylece işlerini işyerinden bağımsız olarak gerçekleştirebilen ve masa başı çalışanlar için pandemi döneminde öne çıan konulardan birisi de uzaktan veya evden çalışma olmuştur.

$\mathrm{Bu}$ dönemde OECD (2020) tarafından ülkelerin uzaktan çalışma kapasitelerinin karantina maliyetlerini etkilediği varsayımıyla hazırlanan bir çalışma yapılmıştır. Bu çalışmaya göre ülkelerin ve bölgelerin uzaktan çalışmaya uyum sağlama kapasitesinin değerlendirilmesi, farklı mesleklerde gerçekleştirilen görevlerin çeşitliliğine dayandırılmış ve iki adımda yapılandırılmıştır: İlk adım, her mesleğin, gerekli görevlere ve bu görevlerin uzaktan gerçekleştirilme derecesine göre sınıflandırılması; ikinci adım ise işgücü anketlerinden elde edilen verilerle farklı meslek türlerinin coğrafi dağılımının değerlendirmesi ve ilk adımda gerçekleştirilen sınıflandırma ile eşleştirmeyi içermektedir. İki veri setinin birleştirilmesi, bölgedeki toplam istihdamın bir payı olarak görevlerini evden gerçekleştirebilecek işçi sayısını değerlendirmeye olanak tanımaktadır. Bu çalışmaya göre uzaktan çalışmanın potansiyeli ülkeler arasında ve içinde büyük ölçüde farklılık göstermiştir. Örneğin, Lüksemburg'da işlerin \%50'si potansiyel olarak evden yapılabilirken Türkiye'de yalnızca \%21'i yapılabilir olarak ortaya çıkmıştır. Bu süreç, uzun vadeli planlarında birtakım işlerin kalıcı olarak uzaktan çalışma şeklinde yapılması yönünde çalışmaları olan şirketler için bir değerlendirme yapmaya olanak sağlamıştır. Böylece uzaktan çalışmanın dezavantajlarına yönelik alınabilecek önlemler üzerinde düşünmeye de fırsat sağlamış ve bu şekilde hem şirketlerin hem de çalışanların yararlarını gözetecek rol ve davranışları öngörmeye yardımcı olmuştur.

Evden çalışmanın bu kadar önemli olduğu bir dönemde şirketlerin verimliliği için evden çalışma uygulamaları ve çalışanlar üzerindeki etkileri en az işyerindeki kadar önemlidir. İş performansı ile ilgili olumlu sonuçlara yol açması nedeniyle çalışanların motivasyonunun bu süreçte nasıl etkilendiğinin belirlenmesi de gerekmektedir. Bu bağlamda araştırmanın amacı, Covid-19 pandemisi nedeniyle beyaz yakalı çalışanların işlerini evden yürütmeleri sırasında çalışma motivasyonlarını etkileyen faktörlerin belirlenmesidir.

Bu çalışmada, aslında bir kriz sayılabilecek pandemi sürecinde, çalışanların bu krize uyum sağlayıp sağlayamadıkları ve bu sürecin çalışma motivasyonlarına etkileri nitel yöntem kullanılarak araştırılmıştır. Araştırma, uzaktan ya da evden çalışmayı bazı işlerde neredeyse zorunlu hale getiren bu sürece geçişin plansız ve hızlı olması nedeniyle çalışan motivasyonu üzerinde ne gibi etkileri olduğunu ortaya çıkarmak açısından önem teşkil etmektedir. Birçok işletmenin orta ya da uzun dönem planlarında yer alan ancak kısa dönem planlarında yer almayan bu çalışma biçimine uyum sağlamak açısından birtakım önlemlerin hızla alınması gerekmektedir. Bu durumda büyük ya da kurumsallaşmış işletmelerin bu sürece daha iyi uyum sağlayacağı söylenebilmekle birlikte; özellikle iyi eğitimli çalışanların ve bu çalışanlara sahip işletmelerin üretkenlik açısından daha avantajlı olduğu da açıktır.

\section{KAVRAMSAL ÇERÇEVE}

\subsection{Uzaktan Çalışma}

Uzaktan çalışma, esnek çalışma modelleri içerisinde yer alan bir çalışma modelidir. Esnek çalışma, insan sermayesini en iyi şekilde kullanmayı amaçlamış ve değişen şartlarla birlikte değişen taleplere uyum sağlamanın bir yolu olarak ortaya çıkmışır. Dolayısıyla günümüz şartlarında ve belki bir süre daha çalışma hayatında söz konusu olacaktır. Çalışma yaşamında esneklik kavramı; TMBB'nin 2014 yılında yayınladığı "Her Alandaki Kadın İstihdamının Artırılması ve Çözüm Önerileri Komisyon Raporu"'na göre, işin yapıldığı mekânın, çalışanların istihdam edilme biçimlerinin ve yapacakları işin niteliğinin, çalışma saatlerinin ve alacakları ücretlerin piyasadaki arz ve talepte görülen artış ve azalışlara göre yeniden düzenlenebilmesine olanak sağlayan bir uygulama olarak ifade edilmektedir. Bu uygulamalar içerisinde yer bulan uzaktan çalışma 
ise bilgi ve iletişim teknolojilerinin kullanılması ile birlikte genellikle merkez bürodan veya üretimin yapıldığı yerden uzak bir yerde yapılan çalışma şekli olarak tanımlanmıştır (Öztürkoğlu, 2013:121).

Covid-19 pandemisi uzaktan çalışma eğilimini başlatan değil ancak ön plana çıkartan bir süreç olmuştur. Çünkü bu süreçten önce de dünyada bazı ülkelerde belli oranlarda uzaktan çalışma benimsenmiş ancak motivasyon ve üretkenlik gibi bazı dezavantajları nedeniyle kimi işletmelerce temkinli yaklaşılmıştır. Uluslararası İşgücü Organizasyonu (2016)'nun raporunda sıralanan; artan bilişim teknolojisi masrafları, dijital güvenlik sorunları, iş ile ilgili kontrol kaybı, iş ve yaşam sınırının karışması, aile ve iş çatışması, tatilde çalışma, iş ile bağını koparamama, sosyal ve profesyonel yaşamdan izolasyon ve kaçırılan fırsatlar gibi uzaktan çalışmanın bazı dezavantajları pandemi döneminde yaşanabilecek dezavantajlar olarak sıralanabilmektedir. Öte yandan Öztürkoğlu (2013:121)'na göre kurumsal bağlllık, kurum kültürü ve örgütsel öğrenme bu durumdan olumsuz etkilenebilmekte ayrıca işe yabancılaşma da meydana gelebilecek dezavantajlar arasında sayllabilmektedir.

Evden çalışma ile ilgili bir diğer konu iş etiğidir. Bilgi toplumu çağının bir gereği olarak evden çalışmanın, hedonik düşünceler ile iş etiğine negatif etkileri söz konusu olsa da yaygınlaştığı için planlamasının bilinçli yapılması, iş verimi ve kaynak yönetimi açısından önemlidir (Kavi ve Koçak, 2010). İş ve yaşam dengesinin evden çalışma konusunda önemli bir yeri vardır. İş ve yaşam dengesi, kişinin, iş ve sosyal alanındaki çıkarlarını gözeterek kişisel sorumluluk ve isteklerini yerine getirmesidir (Chandra, 2012). Clark (2000) iş ve aile alanının psikolojik olarak ayrı yerler olduğunu ve etkileşimlerinin fiziksel, zamansal ve psikolojik sınırların gücüne göre belirlendiğini belirtmiştir. Burada sınırlar; fiziksel, iş veya evdeki fiziksel objelerle ilgili sınırları; zaman, aile ve işe ayrılan vakit ve süre planlaması ile ilgili sınırları; psikoloji, duygu ve düşüncenin iş ve aile alanlarına uygunluğu ile ilgili sınırları belirtmektedir. İş-yaşam dengesini işle ilgili süreçlerin zorlaştırmakta; evden çalışma ise olumlu ancak bazı durumlarda negatif etkilemektedir. Bu nedenle çalışanlar evden çalışma sırasında belirli saatlerde ve işyerindeymiş gibi çalışma ortamı sağlama yönünde tedbirler alabilmektedir. Çünkü iş-yaşam dengesizliği işle ilgili kaygılar, psikolojik, fiziksel ve duygusal olumsuz sonuçlar doğurabilmektedir (Kıcır, 2017).

Bilgi teknolojilerinin sağladığı olanaklar ile işyerinden uzaktan çalışanların sayısı giderek artmaktadır. Yapılan bir çalışmada bilgi işçilerinin cinsiyet, medeni durum, gelir, çocuk sahibi olma durumu ve ev olanakları faktörlerinin evden çalışmalarını etkilediği ortaya çıkmıştır. Yine verimlilik, tatmin ve üstlerle ilişkiler de evden çalışma üzerinde etkili olmakla birlikte işyerinde üstlerinden memnun olmayanların evden çalışmaya daha yatkın oldukları belirlenmiştir (Naktiyok ve İşcan, 2003). Tele çalışma konusunda örgütlerin yaklaşımları bulunduğu sektör, sektörün özellikleri, çalışan sayısı ve teknolojik imkanlara göre değişmektedir. Bu tür bir çalışmaya çoğu örgüt tarafından uygun bulunmazken özellikle bilişim ve araştırma geliştirme alanında faaliyet gösteren işletmeler daha yatkın olabilmektedir (Alkan Meşhur, 2010).

Evden çalışanlar ve işyerinde çalışanlar arasında iş doyumu ve yaşam kalitesi bakımından da farklılıklar vardır. Evden çalışmanın iş doyumu ve yaşam kalitesi üzerinde olumlu etkileri vardır fakat belirli bir seviyeden sonra olumsuza dönüşmektedir. Buna göre çok fazla evden çalışanlarda olumlu etkiler azalmaktadır (Mercan, 2019). Yine pandemi dönemi çalışan anneler için daha memnuniyet verici olmuştur. Çünkü çalışan anneler hem evde ve çocuklarıyla vakit geçirebilmekte hem de çalışmalarını yapabilmektedir. Genel olarak çalışanlar evde işyerindeki gibi masa başında çalışmış ve doküman okuma, operasyonel işler ve iletişim araçlarıyla yapılan işlere yoğunlaşmışlardır. Fakat uzaktan çalışmanın bazı şirketlerde yanlış yönetilerek çalışana evde daha fazla iş yüküne sebep olduğu da görülmüştür (Karaca ve Esen, 2019). Ayrıca evden çalışma ile kişiler çevreleri tarafından işsiz ve evde boş oturuyor gibi göründüğünden yanlış anlaşılmalara ve sosyal sorunlara yol açabilmektedir (Kıcır, 2019).

Randstad firmasının birçok ülkeden topladığı veriler doğrultusunda oluşturduğu rapora göre, çalışanların \%83'ü Covid-19 pandemisi nedeniyle sahip oldukları yeni çalışma ortamına adapte olmuştur. Evde aile ve iş dengesini korurken çalışma saatlerini ayarlayabilenler \%75 iken \%66'sı düzenli çevrimiçi toplantı yapmıştır. Çalışanların \%63'ü pandeminin işleri üzerinde olumsuz etki oluşturduğunu, \%54'ü işlerini kaybetme kaygıSı içerisinde olduğunu ve \%75'i ise işverenlerinin pandemi sürecinde çalışanların sağlıkları ile ilgilendiklerini belirtmiştir (Randstad, 2020). Pandeminin ekonomi üzerindeki etkilerini ölçmeye yönelik birtakım çalışmalar da bu dönemde ön plana çıkmıştır. Örneğin Dingel ve Neiman (2020) COVID-19'un yayılmasını durdurmak için alınan "sosyal mesafe" önlemlerinin ekonomik etkisini değerlendirmek için hangi işlerin uzaktan 
yapılabileceğini belirlemiştir. Bunun için biri iş ortamında kişilerarası ilişkiler, fiziksel çalışma koşulları ve yapısal iş özellikleri gibi işin doğasını etkileyen fiziksel ve sosyal faktörleri açıklamak; bir diğeri de bilgi girişi, başkalarıyla etkileşim, zihinsel süreçler ve iş çıkışı gibi birden fazla işte meydana gelen genel iş davranışları türlerini ortaya çıkarmak amaçlı iki anket kullanılmıştır. Bu anketlerde yer alan koşullardan herhangi biri bir meslek için doğruysa, bu meslek evde gerçekleştirilemeyen bir mesleği olarak kodlanmıştır. Bunlardan bazıları: e-postayı ayda birden az kullandığını söylemesi, şiddete başvuran insanlarla haftada en az bir kez uğraştıklarını söylemesi, en az haftada bir hastalık veya enfeksiyona maruz kaldığını söylemesi, genel fiziksel aktivitelerin gerçekleştirilmesinin çok önemli olduğunu söylemesi, makineleri ve süreçleri kontrol etmenin [bilgisayarlar veya araçlar değil] çok önemli olduğunu söylemesi, halk için performans göstermek veya doğrudan halkla çalışmak çok önemli olduğunu söylemesidir. Amerika Birleşik Devletlerini kapsayan çalışma sonuçlarına göre, Amerika Birleşik Devletleri'ndeki işlerin\% 37'sinin, şehirler ve endüstriler arasında önemli farklılıklar ile tamamen evden gerçekleştirilebileceği ve bu işlere ABD ücretlerinin \% 46'sı gibi bir oranla evde yapılamayan işlerden daha fazlasının ödendiği ortaya çıkmıştır.

\section{2. Çalışma Motivasyonu}

Motivasyon kavramı, eylemi harekete geçiren iç faktörlere ve eyleme teşvik edici olarak hareket edebilen dış faktörlere atıfta bulunur. Motivasyon bir hedefe ulaşma doğrultusunda gayrete ilişkin yoğunluk, istikamet ve kararlılık olarak tanımlanmaktadır. Örgütsel hedeflere odaklanıldığında bu tanımdaki yoğunluk, kişinin hedefine yönelik ne kadar çabaladığı ile ilgiliyken; bu çabanın örgütün faydası istikametinde yönlendirilmesi istenen iş performansına ulaşılmasını sağlayacaktır. Son olarak kararlılık ise kişinin bu çabasını ne kadar koruyabileceği ile ilgilidir. Hedeflerine odaklanmış bireylerin görevi başarıncaya kadar kararlılıkları sürmektedir. Motivasyon, sadece insanların beceri ve yeteneklerinin kazanılmasını değil, aynı zamanda onların becerilerini ve yeteneklerini nasıl ve ne ölçüde kullandıklarını da etkileyebilir. Ancak motivasyon konusunda göz önünde bulundurulması gereken, motivasyonun sadece bireyler arasında farklılık göstermediği; aynı birey için farklı zamanlarda da farklılık gösterebileceğidir (Locke ve Latham, 2004:388; Robbins ve Judge, 2012:204). Buradan hareketle pandemi öncesinde ve sürecinde işgörenlerin çalışma motivasyonlarında değişiklik yaşayabilecekleri söylenebilir.

Çalışma motivasyonu pek çok yazar tarafından sosyal değişim teorisi içerisinde değerlendirilmiştir. Anderfuhren-Biget, Varon, Giauque ve Ritz (2010) tarafından yapılan çalışmada yöneticiler ve kuruluşlar tarafından gönüllü olarak iyi niyetli eylemlerde bulunulduğunda, kamu çalışanlarının bunu takdir ettikleri ve yüksek iş motivasyonu gibi organizasyon için önemli olan yollarla karşıllk verme yükümlülüğü hissettikleri belirtilmiştir. İşyerinde çalışanları yüksek iş motivasyonu ile karşılık vermeye zorladığı tespit edilen eylemler ise adil ödüller, insan kaynakları uygulamaları ve karar alma sürecine katılım olarak sınıflandırılmıştır (Caillier, 2012:465). Bailey ve Kurland (2002:388) tarafından yapılan araştırmada ise esnek çalışma düzenlemelerinin çalışanlara güçlü bir şekilde arzu ettikleri iş-yaşam dengesini sağladığı ifade edildiğinden; onları karşılık vermeye zorlayabilecek başka bir tür gönüllü eylem olduğu ve bunun da kuruluşa çalışma motivasyonunun artması şeklinde bir dönüş sağladığı belirtilebilir (Caillier, 2012:465).

Uluslararası Çalışma Örgütü (2020)'nün yayınladığı “COVID-19 Salgını Sırasında ve Sonrasında Uzaktan Çalışma" adlı rehberde işgörenlerin çalışma motivasyonlarının sağlanması ve devam ettirilmesi için birtakım önerilerde bulunulmuştur. Bunlardan ilki eğitime odaklanmaktır. Çevrimiçi eğitim, web seminerleri, atölye çalışmaları ve koçluk seansları ile ihtiyaç duyulan çeşitli konularda ve özellikle liderlik becerileri, zaman yönetimi becerileri, iletişim becerileri konularında verilecek eğitimlerle çalışanların ihtiyaçlarının karşılanması çalışma motivasyonlarını arttıracaktır. Bir diğeri ise güven ve örgüt kültürüdür. İşgörenleri ile salgının süreçleri ve potansiyel riskleri hakkında açık ve net bir şekilde iletişim kurmakta hızlı davranan ve çalışanlarını uzaktan çalışmanın her yönüyle destekleyen işverenler, yüksek motivasyonlu iş gücünden ve artan güven düzeyinden yararlanmıştır. Bu durum uzun vadede örgütsel kültür üzerinde de olumlu bir etki oluşturacaktır.

\section{YÖNTEM}

Evden çalışma uygulamalarının çalışanların motivasyonları üzerindeki etkilerini inceleyen bu araştırma nitel bir yaklaşım ile ele alınmıştır. Araştırma kapsamında 58 kişi ile yarı yapılandırılmış görüşme formu üzerinden görüşmeler yapılarak veriler elde edilmiştir. Araştırma yönteminin oluşturulmasında çalışmanın yapısına uygun olması nedeniyle nitel araştırma yöntemi kullanılmıştır. "Nitel araştırmalar, gözlem, görüşme ve 
doküman inceleme gibi nitel veri toplama yöntemlerinin kullanıldığı, algıların ve olayların doğal ortamında gerçekçi ve bütüncül bir biçimde ortaya konmasına yönelik sürecin izlendiği araştırmalardır". Nitel araştırmalarda elde edilen sonuçlar evrene mal edilmemekle birlikte, elde edilen sonuçlar, konuya ilişkin bir bakış açısı sağlaması bakımından önemlidir. Bu araştırmanın görüşme tekniği; yarı yapılandırılmış görüşme tekniğidir. Steward ve Cash 1985 yılında görüşmeyi; “Önceden belirlenmiş ve ciddi bir amaç için yapılan, soru sorma ve yanıtlama tarzına dayalı, karşılıklı ve etkileşimli bir iletişim süreci" olarak tanımlamışlardır (aktaran Yıldırım ve Şimşek, 2005:39). Görüşme katılımcılar uzaktan çalışma yapmaya devam etmekte iken ve uzaktan telefon veya online kanallar ile yapılmıştır. Araştırmacılar bilgi toplama sürecinin içinde yer almış ve ayrıca konuyu kendileri de bire bir yaşamıştır. Katılımcıya ilgili sorular sorulmuş ve cevaplara göre soru detaylandırılarak konu hakkında daha fazla bilgi edinmeye çalışılmıştır. Yapılan görüşmeler sırasında katılımcının olabildiğince fazla cevap vermesi için basit müdahaleler yapılmıştır. Katılımcılardan elde edilen cevaplar bilgisayar ortamında belgelere dökülmüştür. Bu dökümler her katılımcıya bir belge olacak şekilde hazırlanmış ve belgelerde soru soru cevaplar işlenmiştir. Daha sonra cevaplar çalışılabilir küçük parçalara ayrılarak kodlanmıştır. Kodlama işleminden sonra veriler kategorilere göre kümelere ayrılacak şekilde özetlenmiştir. Çalışmanın görüşme formu ve ortaya çıkan tema, kategori ve kodlar uzman bir ekip tarafından incelenmiş ve son hali verilmiştir. Kategoriler arası ilişkiler ve analitik genellemeler tümevarım yöntemiyle yapılmışır. Bu araştırmanın etik kurul izni Atatürk Üniversitesi tarafından 27.07.2020 tarihinde 54 sayılı karar ile alınmıştır.

\subsection{Veri Analizi}

Araştırmada kullanılan görüşme formundan elde edilen verilerin sınıflandırılması için nitel analiz programı Nvivo 12 programı kullanılmıştır. Nvivo 12 programı araştırmacılara, belge, resim, ses, video, mülakat ve sosyal medya/internet içerikleri gibi çok geniş yelpazede verileri organize etme ve analiz etmeyi sağlamaktadır (Edhlund ve McDougall, 2019). Çalışmada katılımcılardan elde edilen cevaplar kodlanmış, kodlardan kategoriler elde edilmiş ve temalar oluşturularak içerik analizine tabi tutulmuştur. İçerik analiziyle toplanan veriler incelenerek kavramlar ve ilişkiler açıklanmaya çalışılmıştır.

\subsection{Veri Toplama Aract}

Araştırmacılar tarafından geliştirilen görüşme formu 8 demografik ve 19 açık uçlu sorudan oluşmaktadır. Yarı-yapılandırılmış görüşme formu oluşturulurken ilgili alan yazın incelenerek evden çalışma sürecine ve motivasyona etkisine yönelik sorular oluşturulmuştur. Uzman görüşlerine başvurularak soruların anlaşılırlığı ve geçerliliği sağlanmaya çalışılmıştır.

\section{Katılımcilar}

Araştırmanın çalışma grubu farklı illerde turizm, finans, sanayi, hizmet, reklamcılık, yiyecek içecek, bilişim, hukuk, enerji gibi sektörlerde beyaz yakalı olarak tabir edilen çalışanlardan ve yöneticilerden oluşmaktadır. Çalışmada maksimum çeşitleme ile veri doyumuna ulaşılmaya çalışılmıştır. Çeşitlilik sektörlerde ve farklı görevlerde çalışanlar üzerinden yapılmaya çalışılmıştır. Katılımcılara ait demografik bilgiler Tablo 1'de verilmiştir.

Tablo 1: Katılımcılar ve Demografik Özellikleri

\begin{tabular}{lllllll}
\hline Kod & $\begin{array}{l}\text { Cinsiy } \\
\text { et }\end{array}$ & Yaş & Eğitim & Sektör & İli & Görevi \\
\hline K1 & Erkek & 37 & Lisans & Turizm & İstanbul & İK Müdürü \\
\hline K2 & Erkek & 24 & Lisans & Finans & İstanbul & Yazılım Mühendisi \\
\hline K3 & Erkek & 29 & Yükseklisans & Sanayi & İzmir & Otomasyon Mühendisi \\
\hline K4 & Kadın & 28 & Yükseklisans & Hizmet & Ankara & İK Uzmanı \\
\hline K5 & Kadın & 32 & Yükseklisans & Hizmet & Ankara & Müze Eğitmeni \\
\hline K6 & Erkek & 47 & Lisans & Reklamcılık & - & Editör \\
\hline K7 & Erkek & 38 & Lisans & Sanayi & Ankara & Bölge Sorumlusu \\
\hline K8 & Erkek & 32 & Yükseklisans & Bilişim & Ankara & Yazılım Mühendisi \\
\hline K9 & Kadın & 35 & Lisans & Yiyecek-İçecek & Ankara & Satış ve Dağıtım Sorumlusu \\
\hline K10 & Kadın & 39 & Lisans & Turizm & Diyarbakır & İK Müdürü \\
\hline
\end{tabular}


A. Akbaş Tuna - Z. Türkmendağ 12/3 (2020) 3246-3260

\begin{tabular}{|c|c|c|c|c|c|c|}
\hline K11 & Erkek & 30 & Yükseklisans & Hukuk & Ankara & Hukuk Danışmanı \\
\hline K12 & Kadın & 31 & Lisans & Evcil Hayvan & İzmir & Müşteri İlişkileri Sorumlusu \\
\hline K13 & Erkek & 28 & Lise & Turizm & İzmir & Koordinatör \\
\hline K14 & Erkek & 55 & Lisans & Enerji & Ankara & Faturalama Uzmanı \\
\hline K15 & Erkek & 41 & Yükseklisans & Turizm (İnternet) & Ankara & Strateji Direktörü \\
\hline K16 & Kadın & 33 & Lisans & Çağrı Merkezi & İstanbul & CEO Asistan 1 \\
\hline K17 & Erkek & 37 & Lisans & Turizm & Ankara & Şube Sorumlusu \\
\hline K18 & Kadın & 25 & Yükseklisans & Bilişim & Konya & Web Tasarım Uzmanı \\
\hline K19 & Kadın & 33 & Lisans & Eğitim & Van & Öğretmen \\
\hline K20 & Kadın & 28 & Yükseklisans & Eğitim & Kütahya & Memur \\
\hline K21 & Kadın & 37 & Doktora & Yiyecek-İçecek & Ankara & Özel Müşteriler Yöneticisi \\
\hline K22 & Kadın & 25 & Önlisans & Çağrı Merkezi & İzmir & Müşteri Temsilcisi \\
\hline K23 & Erkek & 44 & Lisans & Sigortacılik & Ankara & Bölge Müdürü \\
\hline K24 & Erkek & 31 & Lisans & Otomotiv & Ankara & İkinci El Müdür Yardımcısı \\
\hline K25 & Erkek & 48 & Lisans & Turizm & İstanbul & Genel Müdür \\
\hline K26 & Erkek & 45 & Lisans & Kimya & Ankara & Satış ve Pazarlama \\
\hline K27 & Erkek & 31 & Önlisans & Yiyecek-İçecek & Ankara & Üretim Müdürü \\
\hline K28 & Kadın & 33 & Lisans & Turizm & Ankara & İK Müdür Yard. \\
\hline K29 & Kadın & 26 & Lisans & Sanayi & Ankara & Muhasebe Çalışanı \\
\hline K30 & Kadın & 36 & Lisans & Bilişisim & Ankara & $\begin{array}{l}\text { Network Saha Operasyon } \\
\text { Mühendisi }\end{array}$ \\
\hline K31 & Kadın & 30 & Lisans & Güvenlik & Ankara & İK Müdürü \\
\hline K32 & Kadın & 50 & Yükseklisans & Sağlık & Ankara & İK Müdürü \\
\hline K33 & Kadın & 28 & Lisans & İlaç Sanayi & İstanbul & Tibbi Tanıtım Temsilcisi \\
\hline K34 & Erkek & 36 & Lisans & Toptan Satış & İstanbul & Bölge Satış Temsilcisi \\
\hline K35 & Kadın & 30 & Lisans & İnşaat & Ankara & İK Sorumlusu \\
\hline K36 & Erkek & 31 & Yükseklisans & Bilişim & Ankara & Penetration Tester \\
\hline K37 & Kadın & 25 & Lisans & Bilişim & Ankara & Müşteri Temsilcisi \\
\hline K38 & Erkek & 25 & Lisans & Havacilık & Ankara & Müşteri Temsilcisi \\
\hline K39 & Erkek & 49 & Lisans & Hızlı Tüketim & $\begin{array}{l}\text { Afyonkara- } \\
\text { hisar }\end{array}$ & Satış Müdürü \\
\hline K40 & Erkek & 22 & Önlisans & Bilişim & Ankara & Yazılım Teknisyeni \\
\hline K41 & - & - & - & - & - & - \\
\hline K42 & Erkek & 28 & Yükseklisans & Yiyecek İçecek & Ankara & Operasyon Sorumlusu \\
\hline K43 & Kadın & 27 & Lisans & Güvenlik & Ankara & Hakediş Memuru \\
\hline K44 & Erkek & 35 & Lisans & Turizm & Ankara & Satış ve Pazarlama Müdür Yrd. \\
\hline K45 & Kadın & 35 & Lisans & Yiyecek İçecek & Ankara & Finans Şefi \\
\hline K46 & Kadın & 42 & Lisans & Üretim & Kocaeli & Yönetici Asistanı \\
\hline K47 & Kadın & 40 & Lisans & Cam Sanayi & İstanbul & Tanzim Teşhir Yöneticisi \\
\hline K48 & Erkek & 25 & Yükseklisans & Yiyecek İçecek & İstanbul & Uzman Satışçı \\
\hline K49 & Erkek & 35 & Lisans & Turizm & Ankara & Call Center Vardiya Şefi \\
\hline K50 & Erkek & 47 & Lisans & Bankacılık & Antalya & Operasyon Yöneticisi \\
\hline K51 & Kadın & 31 & Yükseklisans & STK & Ankara & Finans Uzmanı \\
\hline K52 & Erkek & 46 & Lisans & Bankacilık & Ankara & Şube Müdürü \\
\hline K53 & Kadın & 39 & Lisans & Tercümanlık & Ankara & Mütercim Tercümanlık \\
\hline K54 & Erkek & 26 & Lisans & Hizmet & Iğdır & Çağrı Merkezi Asistanı \\
\hline K55 & Erkek & 36 & Önlisans & Kamu & Kayseri & Büro Elemanı \\
\hline K56 & Erkek & 38 & Yükseklisans & Sağlık & Sakarya & Bilgi İşlem Personeli \\
\hline K57 & Erkek & 27 & Lisans & Finans & Ankara & Uzman Yardımcısı \\
\hline K58 & Kadın & 27 & Lisans & Sigortacılık & Ankara & Portföy Yöneticisi \\
\hline
\end{tabular}




\subsection{Bulgular}

Araştırmanın verileri içerik analizi sonucu yorumlanarak aşağıdaki temalar oluşturulmuştur.

\section{Pandemi Dönemi İş Hayatında Değişim ve Evden Çalışmaya Hazır Olma Durumu}

Pandemi döneminde evden çalışma hayatına geçilerek işle ilgili süreçlerde de değişimler olmuştur. Katılımcıların hepsi evden çalışma yapan kişilerden oluşmaktadır. İş yapılış şekliyle ilgili değişikleri sorduğumuz soruda verilen cevaplara göre katılımcılar pandemi döneminde çalışma saatlerinin esnediğini, toplantı ve görüşmelerin çevrimiçi ortama taşındığını, fiziki para kullanımı yerine havale veya EFT'ye geçildiğini ve raporlamanın arttı̆̆ını belirtmiştir. Bunu katılımcı K51 şe şekilde ifade etmiştir: "İşimi yapış biçimimde olan en önemli değişiklik artık bir mesai kavramına bağlı olmayışımı ve mesaimizin işimizi bitirdiğimizde bitiyor oluşuydu". Ayrıca birçok katılımcı işyerinde yaptıkları işlerinin evde yapılmasının mümkün olmadığını dolayısıyla kısmi olarak evden çalışabildiklerini belirtmiştir.

Pandemi döneminde çalışmaların işyerinden eve aktarılmasında katılımcılar çeşitli zorluklar veya kolaylıklar ile karşılaşmıştır. Bazı masa başı çalışanları çalışmalarını önceden de kısmen uzaktan yaptıkları için teknolojik altyapı ve olanakları ile hazır olduklarını belirtmiştir. Fakat pandeminin hızlı ilerlemesi sonucu ani evden çalışma kararı almış olması nedeniyle 16 katılımcı hazır olamadıklarını belirtmiştir. Bu konuda K42 şunu söylemiştir: "İş yerim uzaktan çalışmaya hazırlıklı değildi. Hiç kimse tahmin edemezdi doğal olarak da şirketimizde tahmin edemedi. Fakat anlık olarak düzeltmeler yapıldı ve şirket bu süreci en hasarsız şekilde atlatmaya çalıştı". Bunun yanı sıra hazır olma durumu sadece işyerinin kendisine değil ayrıca paydaşlarının da hazır olmasına bağlı olduğu için paydaşlarının hazır olma durumları sorulmuştur. Buna göre 8 kişi paydaşlarının operasyonel ve işin yapısı ile ilgili nedenlerle, 20 kişi ise adaptasyon, teknolojik altyapı gibi nedenlerle paydaşlarının hazır olmadıklarını; 23 katılımcı ise paydaşlarının teknolojik altyapıları ile hazırlıklı olduklarını belirtmiştir.

\section{Bilgi Teknolojileri Altyapı ve Güvenlik Önlemleri}

Evden çalışmada en önemli unsurlardan birisi de teknolojik altyapının çalışanın hem kendisinde hem de işyerinde sağlanabilmesidir. Katılımcılara yöneltilen teknolojik altyapı imkanının ne düzeyde olduğuna dair soruya karşılık olarak 30 kişi yeterli bireysel altyapıya sahip olduğunu, 15 kişi işyerinin ekipmanı veya altyapıyı sağladığını ve 18 kişi işyerinin uzaktan erişim için yeterli altyapı sunduğunu söylemiştir. Bunun yanı sıra çevrimiçi çalışma sırasında siber güvenlik ile ilgili bir sorun oluşmadığı ve işyerlerinin çoğunun zaten önceden güvenliği olduğu için fazladan bir yatırıma ihtiyaç duyulmadığ görülmüştür. K35 bu konuda "güvenlik önlemlerimiz yeterliydi covid süreci içerisinde ekstra bir güvenlik aldlk diyemeyiz hali hazırda olan güvenlik sistemlerimiz yeterliydi" ifadesini kullanmıştır.

\section{Çalışanların Evden Çalışmada Yaşadıkları Sorunlar}

Evden çalışmada yaşanan sorunlara yönelik sorulara katılımcıların verdiği cevaplar neticesinde altı kategori oluşturulmuştur. Bu kategoriler çalışma koşulları, iş yapısı ile ilgili sorunlar, iletişim aksaklıkları, psikolojik ve bedensel sorunlardır. Evden çalışmaya geçilmesiyle birlikte en önemli değişimlerden birisi de mesai saati kavramının esnemesi olmuştur. Bazı işyerleri mesai saatlerine riayet etmeye çalışmış fakat birçoğu esnekliği yanlış yorumlayarak çalışma zamanını tüm güne yaymıştır. Katılımcı K18 bu durumu, "Ofis ortamında 09:00 18:00 olan mesai Home Office olduğunuzda değişmektedir. Saat 20:00'de gelen bir mail ile kendinizi masa başında bulabiliyorsunuz. Daha fazla çalışmak kaçınılmaz bir hal almış bulunmaktadır" şekilde örneklendirmiştir. Bunun yanında işlerin aksayacağı ve çalışanın evde boş duracağı kaygısı ile yöneticiler tarafından toplantı sayılarının ve iş yükünün artırıldığı belirlenmiştir.

İşyerlerinin fiziksel ve psikolojik olarak verdiği disiplin ve düzen evde yok olabilmektedir. Özellikle ani pandemi dönemi evden çalışma sürecinde evdeki düzensizlik içerisinde düzenli çalışmaya adapte olabilmek oldukça zordur. Katılımcılar işyerinde daha düzenli çalışabildiklerini ve ev ortamındaki çocukla ilgilenme veya ofis malzemelerinin olmaması gibi iş yapabilecek iyi bir ortamın olmaması evden çalışma önünde sorunlar oluşturmuştur. Bunu katılımcı K29, "sessiz çalışma ortamı oluştururken başta zorluk yaşadım. 10 yaşında bir erkek kardeşe sahibim. Yaşından dolayı televizyon sesi gibi şeylerden ötürü telefon görüşmelerimde zorluk yaşadım" ve başka bir katılımcı da "en önemli sorun dikkat ve odaklanma. Ayrıca evde çocuk bulunduğu için ilave ilgi beklemesi sebebiyle sorun yaşadım" şeklinde belirtmiştir. Bunun yanında kültürel olarak çalışanların uzun zamandır göremedikleri rahatllğıı yaşamaları iş-aile alanı dengesini kuramamalarına sebep olmuştur. Katılımcı K10 bu 
durumu şu şekilde dile getirmiştir: "evde kalmanın vermiş olduğu rahatlıktan dolayı erteleme gibi kötü bir huy edindim. Sabah yapmam gereken işi nasıl olsa evdeyim akşama kadar bitiririm diyordum. Akşam olunca nasıl olsa evdeyim sabah hallederim...". Bu durum bazı çalışanlarda evde rahatlık nedeniyle iş disiplininde azalma ve işleri ertelemeye yol açmıştır.

Evden çalışmada yaşanan diğer bir sorun da işin yapısı ile ilgilidir. İşyerinde yapılabilecek teknik bazı işlerin evde yapılması mümkün olmamaktadır. Özellikle de masa başı iş yapmayanlarda böyle bir durum söz konusu olmuştur. Sanayi gibi ağır makinelerle çalışılan veya turizm gibi müşteri ile anlık ve yüz yüze hizmet sağlandığı sektörlerde evden çalı̧̧mak mümkün değildir. K3 bunu şöyle belirtmiştir: "makine programlamada makine başında makinayı görerek programlamak süreci hızlandırır. Uzaktan çalışmada bu konularda zorluklar yaşadım" Fakat bu sektörler de dahil olmak üzere tüm işyerlerinde muhasebe, satış, insan kaynakları gibi ofis işlerinde çalışanlar işlerini evlerinden yürütebilmişlerdir. Bu tür masa başı iş yapanlarda yine işle ilgili sorunlar ortaya çıkmıştır. Katılımcılar, bilgi teknolojilerinde yaşanan sorunlara acil müdahale edilememesi, e-faturaya geçilmemesi nedeniyle faturalamada aksaklıklar, sslak imza isteyen işlerin aksaması, iş seyahati gerektiren işlerin aksaması gibi birçok sorunla karşılaşmıştır.

Evden çalışma sırasında iletişim aksaklıkları ile karşılaşılmış ve ofis içi kısa iletişimler veya işle ilgili küçük tartışmalar yapılamamıştır. Çalışanlar işyerinde yardım istedikleri bir konuda anında iş arkadaşlarına sorabiliyorken uzaktan bu hemen mümkün olmamıştır. Ayrıca sanal görüşmelere alışık olmayan çalışanlar çeşitli önyargılar nedeniyle bunu yadırgamışlardır. Bu sadece iş arkadaşlarına yönelik değil müşterilerle olan sanal ortamdaki görüşmelerde de farklı olmuştur. Yüz yüze satış yapmanın verdiği satış kabiliyetleri sanal ortamda tam olarak kullanılamamıştır. Bu durumu katılımcı K13 "İnsanlarla temasın azalması yapılacak işlerin çoğunluğunu ve ikna etme potansiyelini etkilemekte" ve K21 "Türk insan olarak yüz yüze iletişim ticari hayatımızda büyük bir önem arz ediyor" şeklinde belirtmiştir. Bu nedenle işyerinde iş arkadaşlarıyla ve müşteriyle iletişim evden çalışma döneminde azalmıştır.

Çalışanların sürekli evden çalışmasının kendi psikoloji ve bedenleri üzerinde olumsuz etkileri olabilmektedir. Çalışma düzeninin bozulması ve işlerin azalması nedeniyle gelecek kaygısı oluşması çalışanlar üzerinde psikolojik sorunlar oluşturmuştur. K34'ün "evde kapalı kalmak psikolojik olarak insanı olumsuz etkiliyor maalesef" cümlesiyle çalışanın sürekli evde kalmaktan olumsuz etkilendiği anlaşılabilmektedir. Ayrıca kapalı kalma sonucu hareketliliğin azalması ve uykuda oluşan problemler de insan vücudu üzerinde olumsuz etkilere neden olmaktadır.

\section{Evden Çalışmanın Avantajları}

Evden çalışmanın zorluklarının yanında birçok avantajı olduğu katılımcıların verdikleri cevaplardan anlaşılmaktadır. Cevaplar sınıflandırıldığında çalışanların çalışma koşulları ve güvenli ortamda çalışma ile ilgili kişisel avantajlar elde ettiği görülmüştür. İşyerinde uzun zamandır belirli bir formda çalışmanın verdiğ $i$ bitkinlik ile evden çalı̧̧maya başlayanlar zamandan tasarruf ettiklerini belirtmiştir. Evden işyerine ve geri dönüşte ulaşımda harcanan vakit ve molalarda harcanan vakit evden çalışmada olmadığından bu vakitleri bir kayıp olarak görmeye başlamıştır. Katılımcı K37 "molalarımı daha verimli kullandım yemek vb. Yol problemi veya uyku sorunu yaşamadım" ve K40 "sabah yolda harcanan süre yerine evimde hem belirli bir süreyi uyumak ve kalan süre zarfında hem kahvaltı hem de kendime vakit ayırmak açısından büyük bir fayda să̆ladı"n belirterek özellikle büyük şehirlerde zamandan nasıl tasarruf ettiklerini belirtmiştir.

Çalışma koşullarında yaşanan diğer değişim ise esnek çalışma saatleri olmuştur. Bu bazı katılımcılarda negatif bir unsur iken çoğu katılımcı bunu avantaj olarak görmüştür. Çalışanlar bu süreçte hem esnek çalışma hem de kıyafet serbestisiyle daha rahat ve kolay bir çalışma düzenine sahip olmuştur. Burada önemli bir husus çalışanın kendi başına kalması ile özerkliğinin de artmasıdır. Bununla birlikte sorumluluk sahibi olan çalışanlar işlerini daha iyi odaklanarak ve yaratıcılıklarını artırarak yerine getirebilmiştir. Buna katkı yapan diğer unsurlar da işyerindeki yoğun stres ortamından, gürültüden ve diğer uyarıcılardan yoksun bir ortamda çalışma fırsatı sunmasıdır. "İ̧slerimizin aksamadığını gördük. Bu şekilde de çok verimli çalışabileceğimizi hem kendimiz fark ettik hem de kanıtladık. Diğer bir avantajı da işe ayrılan süre kısaldı diyebilirim yani o anda bölünme olmadığı için Ofis ortamında odaya gelen ziyaretçi, acil iş, acil toplantı vs. olmadığı için işe ayrılan süreler daha verimli hale gelmeye başladı" görüşünü bildiren K4 odaklanma ve bireysel sorumluluk sayesinde kendi verimliliğinin de arttığını görmüştür. 
Pandemi dönemi çalışmanın en önemli unsuru da tabii ki virüsten uzakta bir çalışma sürdürebilmektir. Çalışanlar sosyal mesafeli bir ortamda ve izole çalışmanın bu dönemde daha güvende hissettirdiğini söylemiştir. Ayrıca evden çalışmanın işyerinde yaşanabilecek bazı iş kazalarının önüne geçtĭginden iş sağlığı ve güvenliğinin de arttığını bildirmiştir. Bunu K18 “virüs ortamında sosyal mesafeden bir haber insanlar ile bir arada olmaktansa evde 1 saat daha fazla çalıșmayı seçmiş birisi olarak daha fazla çalıșmak ve sosyallikten bir nebze uzaklaşmıs olmak benim için sorun yaratmamıştı" ve K38 "Öncelikle evden çalı̧̧manın en büyük avantajlarından birisi, pandemi döneminde insanlarla temas halinde olmamak ve korona virüsüne yakalanma riskinin az olmasıdır" şeklinde ifade etmiştir.

Çalışanın kendisi ile baş başa kalabilmesi ve ailesine ve çevresine daha fazla vakit ayırabilmesi bu dönemin ayırt edici özelliği olmuştur. Sürekli bir düzen içerisinde ve yoğun çalışma temposunda koşuşturan çalışanlar bu dönemde rahat bir nefes alarak çevrelerini görme fırsatı elde etmiştir. Dolayısıyla aileleriyle, arkadaşlarıyla veya hobileriyle daha fazla vakit geçirebilme imkanı elde ederek kendilerine vakit ayırabilmişlerdir. Bu çok önemlidir çünkü insan sosyal bir varlıktır ve işin dışında kendi hayatı ile ilgilenmek için de fırsat kollamaktadır. Çalışanın başarısını sadece işte geçirdiği vakit değil kendi hayatındaki başarısı da etkilemektedir. Dolayısıyla çalışanlar evden çalışma sürecinde çalışanlar hem kendilerini geliştirme fırsatı elde etmiş hem de kariyerlerine odaklanabilmiştir. Katılımcı K10 bu durumu şöyle açıklamıştır: "krizi firsata çevirmek te tabi mümkündü. Bu süreçte iyi şeyler de yaptım. İngilizcemi geliştirebilmek için online kursa katıldım. Yine internet ortamında kişisel gelişim uzmanlarından konuyla ilgili destek aldım" ve "okumak istediğim kitaplarım vard, onları bitirdim".

\section{Örgütsel Faktörlerde Değişim}

Koşulların sağlanmasıyla birlikte evden çalışmaya başlayan katılımcılarda örgüt ile ilgili bazı konularda farklılıklar söz konusu olmuştur. Bunlar sosyalleşme ve takım çalışması, gösterilen çaba ve ast-üst ilişkisidir. K1 işyerinde sosyalleşmenin daha fazla olduğunu "iş yeri, her insanın iyi ya da kötü sosyalleşme yaşadığı yerdir. Sosyalleşme insan psikolojisini olumlu yönde etkiliyor ve motivasyon arttırıcı bir unsur aslında" şeklinde belirtmiştir. İşyerindeki arkadaşlarıyla iletişimlerinin sadece iş üzerinden devam ettiğini K11 "uzaktan çalışıldığı zaman iş arkadaşlar ile iletişimin yalnızca iş üzerinden gerçekleşmesi büyük bir eksiklikti" ifadesiyle belirtilmiştir. K12 de durumu şu şekilde özetlemiştir: "Çalışma ortamı her kesimden farklı insanlar tanımaya, iş sürecinde ve iş süreci dışında o insanlarla sosyalleşmeye, kültürel olarak gelişmeye, iş çevresinin ve sektörel çevrenin gelişmesine olanak sağlamaktadır". Bunun yanında katılımcılar takım çalışmasını tercih ettiklerini ve işyerinin de bunun için ideal bir yer olduğunu düşünmektedir. Katılımcı K32 bu konuyu "farklı görüşlerin, farklı seslerin olması çalı̧malarımızı zenginleştiriyor. Yapıcı tartışma ortamları sağlıyor" ve K52 "takım çalışması iyi olan her işyerinin her zaman devamlılı̆̆ı vardır. Ortak akıl ile alınan kararlar gelecek için çok daha önem arz eder" ş̧eklinde ifade etmiştir.

Örgüt içerisinde gösterilen çabada da evden çalışma sürecinde değişiklikler yaşanmıştır. Çalışma arkadaşları ve amirlerden uzakta olunması nedeniyle daha fazla çaba gösterilmiş ve kendini daha fazla gösterme ihtiyacı duyulmuştur. Buna bağlı olarak çalışanların bireysel sorumlulukları artmış ve ortak işlerde daha fazla sorumluluk almışlardır. Diğer taraftan işleri evde daha kısa sürede tamamlayabilmişlerdir. Evden çalışmaya bağlı olarak örgüt çalışanlarının uzaktan işleri yürütme çabası işyerindekinden daha fazla olsa da bireysel sorumluluğu ve işi daha hızlı yapmayı sağladığı ifade edilmiştir. Ayrıca amirlerin davranışlarında değişimlerin olduğu belirtilmiştir. Bazı çalışanlar amirlerinin destek verdiğini ve daha korumacı ve anlayışlı yaklaşım sergilediğini, bazı çalışanlar ise değişiklik olmadığını veya işler nedeniyle daha katı davranış gösterdiklerini belirtmiştir. Katılımcı K38 bu durumu şöyle belirtmiştir: “Olumsuz olarak daha fazla mobbing uygulaması yapılıyor. Tolere edebilecekleri durumlar azalıyor. Örneğgin iş yerinde mesaiye başlama saati ile evden çalışma sisteminde mesaiye başlama saati konusunda denetlemeler farklılaşıyor çünkü evden çalışma sisteminde iş yerine gitme gibi bir durum gerçekleşmediğinden dolayı mesaiye başlama saatleri konusunda daha denetleyici ve katı davranıyorlar".

\section{Motivasyon Düşürücü ve Artırıcı Faktörler}

Evden çalışma sürecinde uygulamaların katılımcıların motivasyonlarına etkisinin ne olduğuna dair verilen cevaplar motivasyon düşürücü ve artırıcı olarak iki kategoride ele alınmıştır. Bazı çalışanlar ev çalışma ortamının çalışmaya uygun olmaması, evde iş yükünün artması, işyerindeki düzeninin bozulması, iş konusunda belirsizlik ve gelecek kaygısı, işten çıkarmalar olması, işyerinde sosyal ortamda çalışamama nedeniyle motivasyonlarının düştügünü belirtmiştir. Katılımcı K34 konuya ilişkin görüşlerini “Mevcut pozisyonum gereği ofis ortamında ve genel olarak sahada çalısmayı da seven biri olduğum için eve kapanmak zor geldi. 
Bu da motivasyonumun azalmasına sebep oldu ama önceki soruda dediğim gibi motivasyon konusunda gerekli destekleri aldık", "daha çok iş yükü ve mesai oldu ve tek başıma çalışmak motivasyonumu azalttı" ve K3 "Ofis ortamında genellikle disiplin, daha çok işe odaklılık ve belirli bir rutin vardı. Uzaktan çalışmaya geçtiğimizde disiplin azaldı, dikkat dağıtıcı etkenler çoğaldı ve rutini oturtmada zorluklar yaşandı" ş̧eklinde ifade etmiştir.

Bazı çalışanlar evden çalışmanın motivasyonlarını arttırdığını bildirmiştir. Motivasyon artıran unsurlar arasında maddi avantaj ve zaman tasarrufu sağlaması, evde daha fazla vakit geçirebilme ve ev işlerine vakit ayırabilme, evde özerlik nedeniyle iş verimliliğinin ve yaratıcılığın artması, evde rahat ve esnek çalışma fırsatı yakalama ve sağlıklı ve güvenli bir ortam bulunmaktadır. Burada öne çıkan konular özerklik, esnek çalışma ve evde daha fazla vakit geçirebilmektir. Katılımcı K12 bu konuda düşüncelerini "Ev içinde çalışmak 10 dakikalık boşlukları bile kendi ilgi alanlarımla doldurmama ve daha fazla araştırma yapmama olanak sağladı. Yeni şeyler öğrenmek ise bakış açımı oldukça genişletti ve ister istemez yeni fikir oluşumlarının önünü açarak yaratıcllğımla beraber motivasyonumun artmasın sağladı" ve K4 "Daha fazla iş halletmem, kendi hayatıma daha fazla adapte olabilmem evin rahatlığılla bir yandan daha fazla iş halledebildiğimi görmem bana iyi geldi" şeklinde ifade etmiştir.

Çalışmada ortaya çıkan tema, kategori ve bağlı kodlar tablo 2' de listelenmiştir.

Tablo 2: Temalar, Kategoriler ve Kodlar Listesi

\begin{tabular}{|c|c|c|}
\hline Temalar & Kategoriler & Kodlar \\
\hline \multirow{12}{*}{$\begin{array}{l}\text { Evden } \\
\text { Çalışmaya } \\
\text { Hazır Olma }\end{array}$} & \multirow{4}{*}{$\begin{array}{l}\text { Yapılan } \\
\text { Değişiklik }\end{array}$} & Çalışma saatlerinde esneklik \\
\hline & & Görüşmeler ve toplantıların sanal ortama veya telefona taşınması \\
\hline & & Nakit yerine havaleye geçilmesi \\
\hline & & Raporlamanın artması \\
\hline & \multirow{4}{*}{$\begin{array}{l}\text { İşyerinin Hazır Olma } \\
\text { durumu }\end{array}$} & Önceden de kısmen uzaktan çalışıldığı için hazır olma \\
\hline & & Pandeminin ani olması nedeniyle hazır olmama \\
\hline & & Teknolojik altyapı mevcut olduğundan hazır olma \\
\hline & & $\begin{array}{l}\text { Yapılan işin masa başı ve bilgi ağırlıklı olmasında ötürü evden } \\
\text { çalışmaya çabuk adapte olma }\end{array}$ \\
\hline & \multirow{4}{*}{$\begin{array}{l}\text { Paydaşların hazır } \\
\text { olma durumları }\end{array}$} & Operasyonel nedenlerle hazır olmama \\
\hline & & Ani değişim ve plansızlık nedeniyle hazır olmama \\
\hline & & Teknolojik nedenlerle hazır olmama \\
\hline & & Teknolojik altyapıları olduğundan hazır olma \\
\hline \multirow{11}{*}{$\begin{array}{l}\text { Bilgi } \\
\text { Teknolojileri }\end{array}$} & \multirow[t]{4}{*}{ Altyap 1} & İşyerinin evden çalışabilmek için gerekli ekipmanı sağlama \\
\hline & & İşyerinin yeterli uzaktan erişim altyapısı sunması \\
\hline & & Online toplantı ve konferans gibi ortamlar sağlanması \\
\hline & & Yeterli bireysel ağ altyapısına sahip olma \\
\hline & \multirow[t]{7}{*}{ Güvenlik } & İşyerinde yeterli önlemin olması \\
\hline & & Güvenilir bağlantı programı kullanma \\
\hline & & IP kısıtlaması ile güvenlik önlemi alma \\
\hline & & İşyerinde bilgi teknolojileri güvenliği için yeterli önlemlerin olması \\
\hline & & Kişisel bilgisayarda korumaya sahip olma \\
\hline & & Şifreleme ile güvenlik önlemi alma \\
\hline & & VPN ile işyerine bağlanma \\
\hline \multirow{9}{*}{$\begin{array}{l}\text { Evden } \\
\text { çalışmada } \\
\text { yaşanan } \\
\text { sorunlar }\end{array}$} & \multirow[t]{6}{*}{ Çalışma Koşulları } & Çalışma zamanının uzaması \\
\hline & & Toplantı sayısı ve iş yükünün artması \\
\hline & & İşyerinde daha düzenli ve disiplinli çalışılması \\
\hline & & Evde çocuklarla ilgilenme gerekliliğinden doğan sorunlar \\
\hline & & Evde iş yapmak için ortamın olmaması (ofis ekipmanları) \\
\hline & & Rahatlık nedeniyle iş disiplininde azalma ve işleri erteleme \\
\hline & \multirow{3}{*}{$\begin{array}{l}\text { İş Yapısı İle İlgili } \\
\text { Sorunlar }\end{array}$} & İş yerinde yapılabilecek teknik işlerin evde yapılamaması \\
\hline & & $\begin{array}{l}\text { Bilgi teknolojileri ile ilgili yaşanan sorunlara anında cevap } \\
\text { verilememesi }\end{array}$ \\
\hline & & E-Faturaya geçilmemiş olmasından doğan sorunlar \\
\hline
\end{tabular}


A. Akbaş Tuna - Z. Türkmendağ 12/3 (2020) 3246-3260

Islak imzalı evrak işlerinin aksaması veya onay ile ilgili sorunlar

İş seyahatlerinin azalması nedeniyle takipte zorlanma

İletişim Aksaklıkları Ofis içi kısa iletişimin ve küçük tartışmaların yapılamaması

Sanal görüşmelere alışık olmama ve yadırgama

Yüz yüze satış yapılamaması

Psikolojik Sürekli evde kalmanın oluşturduğu psikolojik sorunlar

Çalışma hayatı düzeninin bozulması nedeniyle yaşanan sorunlar

İşlerin azalması ve belirsizlik nedeniyle gelecek kaygısının oluşması

\begin{tabular}{lll}
\cline { 2 - 3 } & Bedensel & Hareketsizlik ve fiziksel sorunlar \\
\cline { 2 - 3 } $\begin{array}{ll}\text { Evden } \\
\text { çalışmanın } \\
\text { avantajları }\end{array}$ & Çalışma Koşulları & Uyku Dengesinin bozulması \\
\cline { 2 - 2 } & & Zamandan tasarruf sağlaması \\
\cline { 2 - 2 } & Esnek çalışma saatlerinin olması \\
\cline { 2 - 2 } & Daha rahat ve kolay bir çalışma hayatı sunması \\
\hline
\end{tabular}

Kiyafet Serbestisi

Serbesti nedeniyle yaratıcılığın gelişmesi

Yoğun stres ve gürültüden uzakta çalışma imkanı

Ofis ortamındaki uyarıcıların bulunmaması nedeniyle daha fazla verimlilik

Güvenli Çalışma İş sağlığı ve güvenliğinin evde daha fazla olması

Ortamı $\quad$ Pandemiden korunarak iş yapabilme olanağı

Kişisel Aile ve çevreye zaman ayırma

Kendine vakit ayırma ve geliştirme

Ulaşım giderinin olmaması

\begin{tabular}{|c|c|c|c|}
\hline \multirow{9}{*}{$\begin{array}{l}\text { Örgütsel } \\
\text { Faktörler }\end{array}$} & \multirow{2}{*}{\multicolumn{2}{|c|}{$\begin{array}{l}\text { Sosyalleşme ve } \\
\text { Takım Çalışması }\end{array}$}} & İşyerinde sosyalleşmenin daha fazla olması \\
\hline & & & İşyerinde takım çalışmasının daha fazla olması \\
\hline & \multirow{3}{*}{\multicolumn{2}{|c|}{ Gösterilen Çaba }} & $\begin{array}{l}\text { Çalışma arkadaşları ve amirlerden uzakta olunması sebebiyle daha } \\
\text { fazla çaba gösterilmesi }\end{array}$ \\
\hline & & & Örgüt içerisinde bireysel sorumluluğun artması \\
\hline & & & İşlerin evde daha kısa sürede tamamlanması \\
\hline & \multirow[t]{4}{*}{ Ast-Üst İlişkisi } & & Amirlerin destek vermesi \\
\hline & & & Daha korumacı ve anlayışlı bir yaklaşım sergilendi \\
\hline & & & Amirlerin tavırlarında değişim olmadı \\
\hline & & & Katı ve agresif yönde davranış değişikliği \\
\hline \multirow{12}{*}{$\begin{array}{l}\text { Motivasyonu } \\
\text { Etkileyen } \\
\text { Faktörler }\end{array}$} & \multirow{6}{*}{\multicolumn{2}{|c|}{ Düşürücü }} & Ev çalışma ortamının çalışmaya uygun olmaması \\
\hline & & & Evde iş yükünün artması \\
\hline & & & İşyerindeki düzeninin bozulması \\
\hline & & & İş konusunda belirsizlik ve gelecek kaygısı \\
\hline & & & İşten çıkarmaların çalışanlar üzerindeki etkisi \\
\hline & & & İşyerinde iş arkadaşları ile çalışamamadan doğan kaygı \\
\hline & \multirow[t]{6}{*}{ Artırıc1 } & & Maddi avantaj \\
\hline & & & Zaman tasarrufu \\
\hline & & & Evde daha fazla vakit geçirebilme ve ev işlerine vakit ayırabilme \\
\hline & & & Evde özerklik nedeniyle iş verimliliğinin ve yaratıcılığın artması \\
\hline & & & Evde rahat ve esnek çalışma ortam \\
\hline & & & Sağlıklı ve güvenli bir ortam \\
\hline
\end{tabular}

Nvivo 12 programı ile elde edilen kelime bulutuna göre katılımcılar daha çok eğitim, takım, dijital, değişim, güvenlik, zaman, internet, görüşme, telefon, olumlu, çalışan kelimelerini tekrar etmiştir (Şekil 1). Bu kelimeler kullanım sıklıklarına paralel olarak kodlarda da kullanılmıştır. Ayrıca bu kelimeler uzaktan çalışmada değişimin özellikle bu konularda yaşandığını ve daha önemli hale geldiğini göstermektedir. 


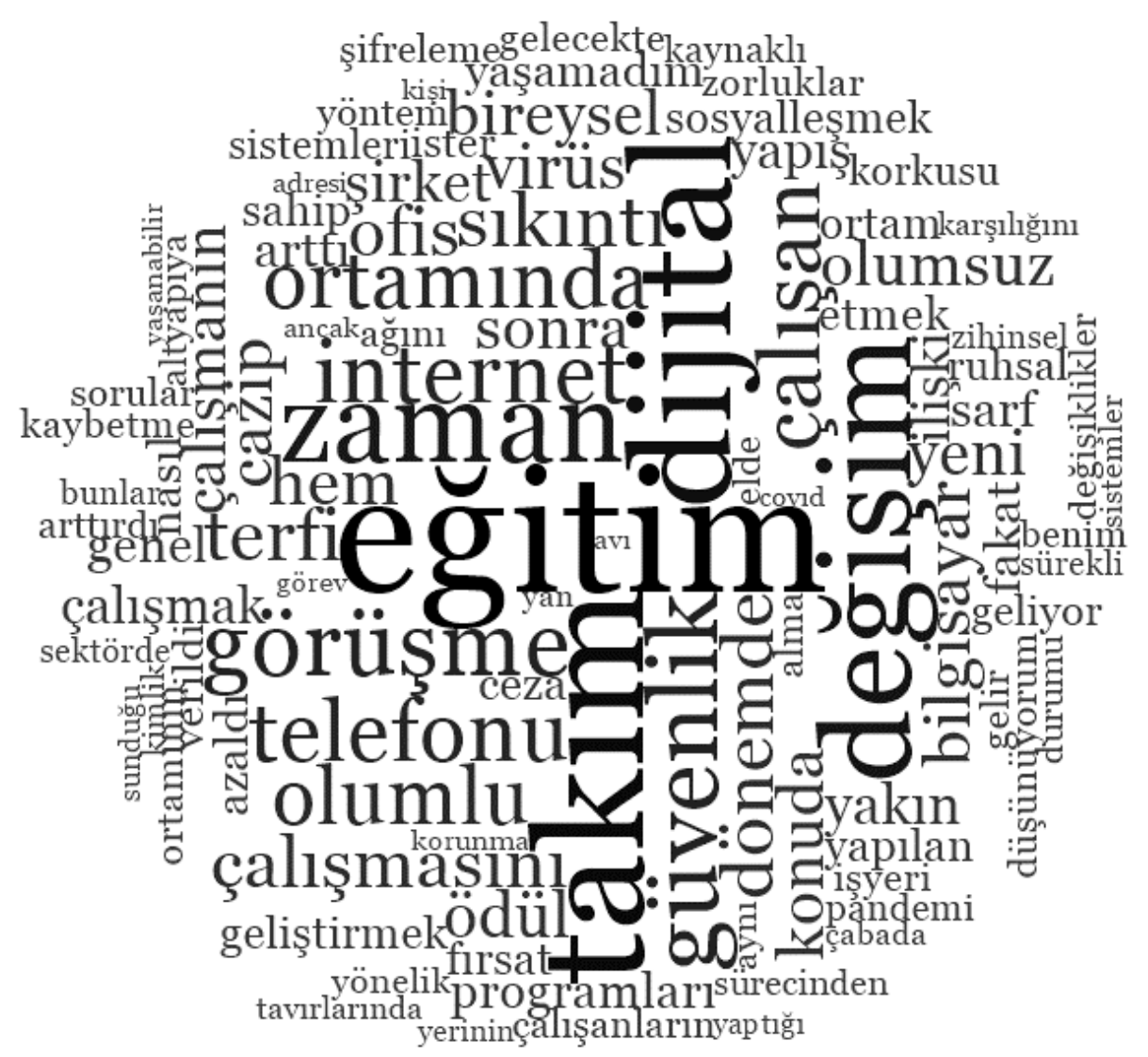

Şekil 1: Kelime Bulutu

\section{SONUÇ VE TARTIŞMA}

Yönetim alanında motivasyon çalışmalarının çokça yapıldığı bilinmektedir. Uzaktan çalışma ve çalışma motivasyonu ile ilgili de pandemi döneminden önce yapılmış bazı çalışmalar bulunmaktadır. Alan yazın incelendiğinde pandemi döneminde uzaktan çalışma ve çalışma motivasyonu ilişkisini araştıran bir çalışmaya rastlanmamıştır. Bu döneme kadar motivasyon ile ilgili yapılan çalışmaların pek çoğunda esnek çalışmanın işgörenlerin motivasyonlarına nasıl bir etkide bulunacağ 1 bu süreci deneyimlemeyen işgörenlerden alınan bilgilere dayanmaktaydı. Ancak ilk kez böyle zorunlu bir süreci pek çok işgören deneyimlemek durumunda kalmıştır. Bundan dolayı işgörenlerden elde edilen bilgilerin bir kısmı mevcut araştırmaları desteklerken bir kısmı da farklı sonuçlara ulaşılmasını sağlamıştır.

Pandemi döneminde de anlaşıldığı üzere evden çalışma bilgi teknolojilerinin gelişimi ile modern çalışma hayatının bir parçası haline gelmiştir. Fakat evden çalışmayı başarabilmek de en az işyerinde çalışma kadar anlaşılması zor bir süreçtir. Çalışanın işyerindeki düzenini bırakarak evde çalışma düzenine geçmesinde bazılarının hazır olduğu bazılarının ise olmadığı görülmüştür. Öncelikle yapılan işin yapısı uzaktan çalışmaya elverişli olup olmama durumu çok önemlidir. Örneğin turizm, sanayi, taşımacılık gibi sektörlerde işin yapısı gereği uzaktan çalışmak mümkün olmamaktadır. Bu sektörlerde muhasebe, insan kaynakları gibi destek birimler veya ofis çalışanları uzaktan çalışma yapabilmektedir. Çalışma saatlerinde esneklik, teknolojik altyapı olanakları, önceden evden çalışma tecrübesi, yapılan işin masa başı olup olmaması ve paydaşların da bu süreçte hazır olma durumları çalışanın evde işe hazır olma durumlarını etkilemektedir. Bu hususta çalışanların evden çalışma uygulamalarını gerçekleştirebilmeleri için yapılan işe, işyerinin teknoloji ve planlama ile hazır olması ve paydaşlarının da hazır olma durumlarını bilmeleri önem arz etmektedir. Bilgi teknolojileri altyapısı evden çalışmanın olmazsa olmazı olarak çalışma şeklini doğrudan etkilemektedir. Bu konuda işyerleri çalışanlarına gerekli ekipmanı sağlamakta, eğer gerekliyse işyerine uzaktan erişim altyapısını sunma ve online toplantılar için ortam sağlamaktadır. Sadece altyapı bilgi teknolojileri için yeterli değildir, bunun yanında güvenlik unsurları da irdelenerek gerekli önlemler alınmaktadır.

Evden çalışmada karşılaşılan sorunlar ve avantajları konusunda bazı çalışanlar aynı unsurlara farklı yaklaşımlar göstermiştir. Örneğin bir çalışan çalışma zamanındaki esnekliği düzensizlik olarak, bir diğer 
çalışan bunu odaklanma için ideal ortam olarak algılamıştır. Nihai olarak çalışma koşullarındaki değişiklikler çalışanın evden çalışmasında sorunlar veya avantajlar oluşturabilmektedir. Bunun yanında işin yapısı veya bilgi ağırlıklı olmaması ile ilgili sorunlar da çalışmayı etkilemektedir. Evden çalışmanın yapılabilmesi için çalışanın yaptığı işin bilinmesi gerekmektedir. İşyerinde çalışan bireyler iç içe olduklarından sürekli bir iletişim içerisindedir fakat evden çalışmada bu uzaklık nedeniyle aksayabilmekte ve resmileşmektedir. Ofiste iş arkadaşları veya amirler ile yardımlaşma, kısa iletişimler veya tartışmaların işin ilerlemesindeki önemi çoktur. Ayrıca psikolojik ve bedensel sorunlar da düzensizlikten ve hareketsizlikten ortaya çıabilmektedir.

Pandemi döneminde evden çalı̧̧manın işyerinde çalışmaya göre avantajları da katılımcılar tarafından belirtilmiştir. Esnek çalışma saatleri ve rahat çalışma, kıyafet serbestisi ve yoğun stresten uzakta bir hayat ve çalışmanın avantaj olduğunu düşünmektedir. Aynı zamanda ulaşım giderlerinin azalması da bir avantaj olarak belirtilmiştir. Evde güvenli çalışma ortamı sayesinde işyerinde virüs alma riski azalmaktadır. Bunun yanında çalışanlar evden çalışma sayesinde aile, çevre ve kendilerine daha fazla zaman ayırabilmiştir. İşte verimlilik esas alındığında çalışanın sosyal hayatındaki başarısı ve kendini görebilme fırsatı önemli unsurlardır. Bu dönemde çalışanlar işten artan vakitte evlerinde kariyer gelişimlerini ve farklı alanlarda gelişimlerini sağlamaktadır. Araştırmadaki birtakım bulgular pandemi döneminden önce yapılmış bazı çalışmalarla örtüşmemektedir. Örneğin Bailey ve Kurland (2002:387) araştırmalarında bireylerin neden uzaktan çalıştıklarına yönelik bir araştırma sorusu oluşturmuş ve 1970'lerde yaşanan petrol krizinden kaynaklı işe gidip gelme şeklinde seyahat azaltmanın, tele-çalışma için güçlü bir motivasyon kaynağı olmadığının kanıtlandığı pek çok çalışmaya atıfta bulunmuştur. Ayrıca tele-çalışmaya ilginin çocuğu olmayan çiftler arasında, bir ila iki çocuklu çiftler arasında olduğundan daha güçlü olduğuna ve küçük çocukları olan tele-çalışanların çocuk yetiştirme ile iş arasında denge kurmakta zorlandıklarına dair çalışmaları raporlayarak; bugüne kadar elde edilen kanıtların, aile kaygılarının kadınları tele-çalışmaya yönlendireceği hipotezini zayıflattığına da değinmişlerdir.

Torten vd. (2016:317)'ne göre evden çalışmanın benimsenmesinin başarısı, çalışanın böyle bir iş düzenlemesine açıklığı ve hazırlığı, şirketin açıklı̆̆ ve böyle bir modelden yararlanma arzusu ve başarısını sağlayabilecek bir bilgi ve iletişim teknolojisi altyapısı dahil olmak üzere birçok faktöre bağlıdır. Bu araştırmaya göre de plansız ve hızlı bir geçiş yaşanan evden çalışma sürecinde ideal olarak istenen başarının sağlanamadığ 1 söylenebilir.

Evden çalışmada örgütsel bazı süreçler de değişmektedir. Tüm çalışanların evden çalışması nedeniyle örgütte sosyalleşme ve takım çalışması yavaşlamakta, gösterilen çaba azalmakta, bireysel sorumluluk artmakta ve astüst ilişkileri farklı bir ortama taşınmaktadır. Bazı amirler destek ve anlayış ile bazıları ise kontrolcü, katı ve agresif tavırlar içerisinde işleri yürütmeye çalışmaktadır. Ayrıca katılımcılar bu tema altında sosyalleşmenin insan psikolojisini olumlu yönde etkileyen motivasyon arttırıcı bir unsur olduğunu ve uzaktan çalışıldığı zaman iş arkadaşları ile iletişimin yalnızca iş üzerinden gerçekleşmesinin büyük bir eksiklik olduğunu belirtmişlerdir. Tetik (2019) tarafından yapılan sosyalleşmenin iş motivasyonu üzerindeki etkisine yönelik yapılan araştırmada da sosyalleşmeyi ölçen alt boyutlardan sadece iş arkadaşlarının desteği boyutunun iş motivasyonu üzerinde anlamlı bir etkisi olduğu sonucuna ulaşılmıştır. Öte yandan Can ve Koç (2019) tarafından yapılan ve sektörlere göre motivasyon araçlarının algılanma düzeylerine yönelik araştırmada, motivasyon aracı olarak arkadaşlarla olan bireysel ilişkiler ifadesi, elektrik dağıtımı ve ulaştırma hizmetlerinde çalışanlar arasında yüksek düzeyde ancak diğer faktörlere göre en az motive olunan araç olarak seçilmiştir. Sözü geçen sektörlerde çalışanların beyaz yakalı çalışanlar olmadığı düşünüldüğünde bu çalışmadaki sonuçlarla farklılık göstermesinin mümkün olduğu söylenebilir.

Evden çalışma uygulamalarının motivasyon üzerindeki etkisinin düşürücü veya artırıcı olduğu katılımcılar tarafından belirtilmiştir. Bazı çalışanların işyerindeki düzenin bozulması ve evdeki çalışma ortamının iş yapmaya uygun olmaması nedeniyle motivasyonları düşmüştür. Çalışma koşulları morali yükseltmede önemli rol oynamaktadır (Eren, 2012). Bu nedenle evden çalışmada yeterli ortamın sağlanması gerekmektedir. Evde çalışacak kişi çocuk ve aileden izole bir şekilde kendi alanında çalışarak daha fazla odaklanma şansı elde edebilir. Ayrıca evde iş yükünün artması nedeniyle motivasyonun düştüğü de bildirilmiştir. Amirlerin güvensizlik veya aşırı kontrol ihtiyaçları nedeniyle daha fazla raporlama isteği veya çalışan evde çalışmayacak kaygısı farklı davranışlara yöneltebilmektedir. Bu konuda amirlerin çalışanlarına güvenmeleri ve bu güven temelinde işlerini yürütmeleri önem arz etmektedir. Çalışanların da katılımı ile yapılacak iyi bir evden çalışma planı hem çalışan hem de amir için bir sözleşme niteliğinde olacaktır. İşyerinde süregelen çalışma şekillerinin 
farklılaşması amir tarafından iyi yönetilemez ise sonuçları iyi olmayan bir sürece sokabilir. Evden çalışma, işletmeler için çoğu şeyin farklılaştığı ve çalışanın kendisini tanıma fırsatı bulduğu bir süreçtir. Çalışanlar bu süreç sonunda amirleriyle arasını bozabilir, farklı bir yer arayışına girebilir veya çalışma arkadaşlarına daha da bağlanabilir. Dolayısıyla işletmeler etkin bir iletişim ile çalışanlarına planlarını aktarmalı, daha çok ortak çalışılabilecek sanal ortamlar oluşturmalı ve nasıl çalışılması gerektiği konusunda araştırma yaparak eğitim vermelidir.

Çalışanları evden çalışma uygulamalarında motive eden maddi avantaj elde etme ve zaman tasarrufu sağlama konusu işletmeler tarafından dikkate alınmalıdır. Evden çalışmada elde edilen tecrübeler pandemi sonrası işyerinde çalışmaya aktarılarak çalışan motivasyonları artırılabilir. Katılımcıların cevaplarından anlaşıldığı üzere çalışanlar aileleriyle daha fazla vakit geçirebildikleri esnek ve özerk çalışma ortamlarında daha verimli olabilmektedir. Bunun için işyerinde bu unsurlara yönelik değişiklikler yapılabilir veya yarı zamanlı uzaktan çalışma modellerine geçiş yapılabilir. Nitekim çalışanın işteki hırsına etki eden en önemli etkenlerden birisi de aile yaşamıdır (Eren, 2012). İş-aile yaşam dengesinin iyi kurulması çalışanın tüm çalışma hayatını etkileyen önemli bir unsur olarak daha da moral verebilmektedir. Ayrıca özerklik ve esneklik işletmeleri ve yöneticileri genellikle korkutan kavramlar olmuştur. Halbuki çalışmalar bu unsurların verimlilik ve yaratıcılığı artırdığını göstermektedir (Wang ve Cheng, 2010). Çalışan kişi kendi ile baş başa kalabildiğinde hem kendisini tanıabilecek hem de yaptığı işi daha iyi görebilecektir. Bunu takiben hem kendisini hem de yaptığı işi geliştirme yönünde girişimleri olacaktır. Fakat bunu yaparken işletmenin yaklaşımı ve sağladığı güven ortamı önemlidir. Aksi takdirde evden çalışma da motivasyonsuzluğa neden olabilmektedir.

Covid-19 pandemi döneminde çalışanlar için en önemli konu virüsten uzakta kalarak sağlıklı yaşam sürebilmektir. Bu nedenle evden çalışmak sağlıklı bir ortam oluşturduğu için motivasyonlarını artırmıştır. Bu aslında işyerinin çalışanlarına verdiği önemle de doğru orantılı olarak çalışan tarafından algılanmaktadır. Birçok işyeri maalesef işyerinde çalışmaya devam ederek çalışanlarının sağlıklarını ikinci plana atmış ve işyerinde tedirgin olmalarına yol açmıştır. İşletmeler çalışanlarına evden çalışma şansı tanıyarak hem motivasyonlarını yükseltmiş hem de verimliliklerini artırmıştır. Bu sürecin çok uzaması çalışanlarda motivasyonsuzluğa yol açabilmektedir. Ancak işletmelerin çalışma motivasyonuna sahip işgörenlerle çalışmayı tercih ettikleri de bir gerçektir. Chen (2012)'in çalışmasında işletmeler için, daha yüksek iş otonomisine ve iş motivasyonuna sahip kişilerle çalışılmasının temel bir gereksinim olduğu ve bu iki özelliğe sahip çalışanların, uzaktan çalışmayı kolayca yürütebileceği belirtilmiştir.

Gelecek çalışmalar pandemi nedeniyle örgütsel değişmeleri ve çoklu çalışma tarzlarını ele alabilir ve evden çalışmanın nasıl daha verimli hale getirilebileceği konusuna odaklanabilir. Evden çalışmanın gelişmiş bilgi teknolojileri ile çalışma hayatının bir parçası olduğu düşünülürse farklı sektörlerde uzaktan çalışmayı irdeleyen nicel araştırmalar konuya daha ayrıntılı yaklaşımlar sunabilir.

\section{KAYNAKÇA}

Alkan Meşhur, H. F. (2010). Organizasyonların Tele Çalışmaya İlişkin Tutumlarına Yönelik Bir Araştırma. Dokuz Eylül Üniversitesi İktisadi ve İdari Bilimler Fakültesi Dergisi, 25(1), 1-24.

Anderfuhren-Biget, S., Varone, F., Giauque, D., \& Ritz, A. (2010). Motivating employees of the public sector: does public service motivation matter?. International public management journal, 13(3), 213-246.

Bailey, D. E., \& Kurland, N. B. (2002). A review of telework research: Findings, new directions, and lessons for the study of modern work. Journal of Organizational Behavior, 23, 383-400.

Caillier, J.G. (2012). The Impact of Teleworking on Work Motivation in a U.S. Federal Government Agency, American Review of Public Administration 42(4) 461-480.

Can, M., ve Koç, H. (2019). Motivasyon Araçlarının Algılanma Düzeylerinin Sektörlere Göre Analizi, İşletme Araştırmaları Dergisi, 11 (4), 3458-3470.

Chandra, V. (2012). Work life balance: eastern and western perspectives, The International Journal of Human Resource Management, 23: 5, 1040-1056.

Chen, H-C. (2012). The feasibility study of teleworking, Department of Business Management, National Sun Yat-sen University, Master Thesis. 
A. Akbaş Tuna - Z. Türkmendağ 12/3 (2020) 3246-3260

Clark, S. C. (2000). Work-family border theory: A new theory of work-family balance, Human Relations, 53 (6), 747-770.

Dingel, J.I. and Neiman, B. (2020). "How many jobs can be done at home?," Journal of Public Economics, vol $189,104235$.

Edhlund, B., \& McDougall, A. (2019). NVivo 12 essentials. Stallarholmen: Form \& Kunskap AB

Eren, E. (2012). Örgütsel Davranış ve Yönetim Psikolojisi (13. Baskı). İstanbul: Beta.

International Labour Office (2016). Challenges and opportunities of teleworking for workers and employers in the ICTS and financial services sectors: Issues paper for the Global Dialogue Forum on the Challenges and Opportunities of Teleworking for Workers and Employers in the ICTS and Financial Services Sectors (Geneva, 24-26 October 2016).

Karaca, S. ve Esen, E. (2019). İş Yeri İnovasyonunun Bir Örneği Olarak Uzaktan Çalışmanın İş-Yaşam Dengesine Etkisi: Çalışan Anneler Üzerine Bir Araştırma. International Social Innovation Congress, 16-17 October 2019, 11-22.

Kavi, E. ve Koçak, O. (2010). Bilgi Toplumunda Evden Çalışmanın Etik Boyutu. Sosyal Siyaset Konferansları, $59,69-88$.

Kıcır B. (2017). Evden Çalışanlarda Iş-Yaşam Dengesï: Çevïrmenler Üzerïnde Bïr Araştırma. Is, Guc: The Journal of Industrial Relations \& Human Resources, 19(4), 133-157.

Kıcır, B. (2019). Evden Çalışma: Özgürlük mü Esaret Mi?. Dokuz Eylül Üniversitesi Sosyal Bilimler Enstitüsü Dergisi, 21(1), 173-196.

Locke, E. A., \& Latham, G. P. (2004). What should we do about motivation theory? Six recommendations for the twenty-first century. Academy of Management Review, 29, 388-403.

Mercan, M. B. (2019). Bankacılık Sektöründe Çalışanların Sosyodemografik Özellikleri ve Evden Çalışıp Çalışmama Durumuna Göre İş Doyumu, Örgütsel Bağlllık ve Yaşam Kalitesi Açısından Durumlarının Değerlendirilmesi (Yayımlanmamış Yükseklisans Tezi). Maltepe Üniversitesi Sosyal Bilimler Enstitüsü, İstanbul.

Naktiyok, A. ve İşcan, Ö. F. (2003). İş görenlerin Evden Çalışmaya İlişkin Tutumları: Bireysel Özellikler ve İş Sürükleyicileri Açısından Bir Uygulama. Akdeniz İ.̇̇.B.F. Dergisi, 6, 53-72.

OECD (2020). Capacity for Remote Working Can Affect Lockdown Costs Differently Across Places, erişim: https://read.oecd-ilibrary.org.

Öztürkoğlu, Y. (2013). Tüm Yönleriyle Esnek Çalışma Modelleri. Beykoz Akademi Dergisi, 1 (1), 109-129.

Robbins, S. P ve Judge, T. A. (2012). Örgütsel Davranış (Çeviri Editörü: İnci Erdem), Nobel Akademik Yayıncilik: Ankara.

Tetik. S. (2019). Kamu Örgütlerinde Örgütsel Sosyalleşmenin İş Motivasyonu Üzerindeki Etkisi: İhsaniye İlçesinde Bir Araştırma, İşletme Araştırmaları Dergisi, 11 (3), 1779-1791.

TMBB (2014). Her Alandaki Kadın İstihdamının Artırılması ve Çözüm Önerileri Komisyon Raporu, Kadın Erkek Fırsat Eşitliği Komisyonu Yayınları No: 12.

Toren, C., Reaiche, C. ve Caraballo, E. (2016). Teleworking in the new milleneum, Journal of Developing Areas. June, Vol. 50 Issue 5, p317, 10 p.

Uluslararası İşü̈cü Organizasyonu (2020). Teleworking during the COVID-19 pandemic and beyond A practical guide Geneva, July.

Wang, A.-C. and Cheng, B.-S. (2010), When does benevolent leadership lead to creativity? The moderating role of creative role identity and job autonomy. J. Organiz. Behav., 31: 106-121.

Yıldırım, A. ve Şimşek, H. (2005). Sosyal Bilimlerde Nitel Araştırma Yöntemleri, Ankara: Seçkin Yayıncılık. https://workforceinsights.randstad.com/hr-research-reports/workmonitor-covid19-june 